\title{
Coping Strategies for Battered Women regarding Domestic Violence
}

\author{
Lamiaa Moustafa Ali Elbosaty¹, Nawal Mahmood Soliman² and Huda Abdallah Moursi ${ }^{3}$ \\ (1) Head nurse of specialized surgeries department, Emergency hospital, Mansoura University, Egypt \\ (2) Professor of Community Health Nursing, Faculty of Nursing, Ain - Shams University, Egypt and (3) \\ Lecturer of Community Health Nursing, Faculty of Nursing, Benha University
}

\begin{abstract}
Background: Domestic violence is a serious epidemic problem and a major public health concern; it violates the fundamental human rights of women. Although many countries have lows that criminalized domestic violence, it occurs in all cultures without the considerations of social, economic, race, nationality, and religious groups. Aim of study: Was to evaluate the effect of coping strategies for battered women regarding domestic violence. Research design: A quasi-experimental design was used in carrying out this study. Setting: This study was conducted at two centers for the care and hosting of abused women in Benha and Mansoura Cities. Sample: A simple random sample of 107 battered women. Tools of data collection: Two main tools were used, I: A structured interviewing questionnaire which consists of four parts to assess A): Socio demographic characteristics of the studied battered women, B): Battered women's knowledge regarding domestic violence, C): Women's practices scale and D): Women's attitude scale and II: Cope scale to measure the coping skills of battered women regarding domestic violence. Results: $76.6 \%$ of the studied battered women had good knowledge about coping strategies post-intervention, $72 \%$ of the studied battered women were satisfactory practices in coping strategies post-intervention, $27.1 \%$ of the studied battered women had a positive attitude regarding domestic violence post-intervention, $69.2 \%$ of the studied battered women had good coping abilities post-intervention. Conclusion: The coping abilities regarding domestic violence for battered women were improved post-coping strategies implementation. Recommendations: Continuous coping strategies programs for battered women to increase their knowledge and improve their practices and attitude.
\end{abstract}

Keywords: Battered women, Coping Strategies, Domestic violence,

\section{Introduction:}

Domestic violence is a global problem that crosses cultural, geographic, religious, social, and economic boundaries and is a violation of human rights. Violence against women deprives women of their right to fully take part in life. Violence causes a myriad of physical, mental, financial, sexual, and spiritual health issues and in some cases results in loss of life. Although various steps have been taken by governmental and non-governmental organizations, the problem of domestic violence is still at its most serious level (Salvatore, 2018).

World Health Organization (WHO) estimates that $30 \%$ of women worldwide have been exposed to violence. The prevalence estimates of lifetime intimate partner violence

\section{JNSBU}




\section{Coping Strategies for Battered Women regarding Domestic Violence}

range from $20 \%$ in the Western Pacific, $22 \%$ in high-income countries and Europe, and $25 \%$ in the Americas to $33 \%$ in the African region, $31 \%$ in the Eastern Mediterranean region, and $33 \%$ in the South-East Asia region (WHO, 2021). In Egypt 7.8 million women suffer from all forms of violence yearly, whether perpetrated by individuals in close circles or from strangers in public places. More than one-third $(36 \%)$ of ever-married women between ages (15- 49) have experienced physical violence since the age of 15 (United Nations Population Fund Activities (UNFPA), 2019).

Violence against women is considered a major public health concern worldwide due to high morbidity and mortality. It has substantial public health consequences, including both general health and reproductive health consequences such as chronic pain, injuries, fractures, disability, unwanted pregnancy, contraceptive use, rates of human immune defiance virus, and other sexually-transmitted infections. Victims of domestic violence also suffer from psychological disturbances. In addition, it has an adverse effect on the economic progress of a country in the form of increased economic costs including loss of women's labor hours and increased healthcare costs (WHO, 2016).

Coping strategies refer to the specific efforts, both behavioral and psychological, that people employ to tolerate, reduce stressful events. Two general coping strategies have been distinguished: Problem-solving strategies which efforts to active to alleviate stressful circumstances, whereas emotion-focused coping strategies involve efforts to regulate the emotional consequences of stressful or potentially stressful events. People usually use both types of strategies to combat most stressful events (Taylor, 2012).

Coping is one of the most important and widely studied aspects of domestic violence. Women adopt a wide variety of coping strategies to manage abuse, including seeking help, spiritually, silence, not answering back, leaving the husband permanently or temporarily. Some survivors choose to be in denial and tend to ignore what is going on, some women are unable to make their own decisions or even protect themselves and their children from the fear of preparator's repercussions and of being stigmatized in their society. Coping efforts are often constrained by factors such as lack of social support, financial dependence, and severity and length of violence; there are two functions of a coping strategy: (a) to regulate distress and (b) to manage the problem that is causing that distress (Mahapatro, 2018)

Community health nurses play an important role in the fight against domestic violence by using their unique skills like health education which provide positive change effect in the health behavior of individuals and the community and raise awareness about the harmful effect of domestic violence. Furthermore, she used her counseling skill to counsel an individual who is at risk or exposed to domestic violence and gives the clients strategies for their own safety. Also, the community health nurse assists women to recognize any dangerous behavior of her partner which may indicate impending danger or abuse and taking action like leaving the environment, keeping quiet and not talking back at the partner, and making a plan of action for

\section{JNSBU}




\section{Lamiaa Moustafa, Nawal Soliman and Huda Abdallah Moursi}

any dangerous situation they may encounter (Tomasz, 2019).

\section{Significance of the study:}

In Egypt 7.8 million women suffer from all forms of violence yearly, whether perpetrated by individuals in close circles or from strangers in public places. more than onethird $(36 \%)$ of ever-married women between ages (15 - 49) have experienced physical violence since the age of 15. In Egypt gender disparities are pronounced, the Gender Inequality Index of Egypt is 116 out of 189 countries as per the 2018 Human Development Report (UNFPA, 2019). Domestic violence is a major social health problem that affected all communities especially women and will remain a challenge for the future. This study will enhance the health and coping abilities of battered women, increase battered women's knowledge, attitude, and practice regarding domestic violence coping strategies.

\section{Aim of the study:}

This study aimed to evaluate the effect of coping strategies for battered women regarding domestic violence.

\section{Research hypothesis:}

Coping strategies implementation would improve battered women coping abilities regarding domestic violence.

\section{Subject and method:}

\section{Research design:}

A quasi-experimental design was used in carrying out this study.

\section{Setting:}

The study was conducted at two centers for care and hosting of battered women followed by the Ministry of Social Solidarity in Benha City at the Center of Complex Integrated Women Services, which is located at faculty of medicine street in front of Benha Sporting Club, and in Mansoura city at Mowasat Islamic Charity, which located at Mahmoud Shaheen Street in front of El Essawy Mosque, Supplement to Dar El Amal for the Elderly.

\section{Sampling:}

A simple random sample was used, attended to previously mentioned setting throughout 6 months from the beginning of the study with the following criteria: free from any handicapping, not divorced, and not resident in the centers for care and hosting of battered women. The total number of studied battered women was 107 after excluding the pilot study participation.

Tools for Data Collection: Two tools were used to collect the data:

\section{Tool (I): A structured interviewing} questionnaire: It was developed by the researcher based on the literature review of the current and past available national and international references related literature battered women by using a journal, textbooks, and internet search, approved by supervisors and it was written in simple clear Arabic language: It comprised of four parts to assess the following:

The first part: Was designed of four items to assess socio-demographic characteristics of battered women involved in the study, to assess demographic characteristics of perpetrators men, and to assess the types of violence against battered women

The second part: Was designed to assess the level of battered women's knowledge regarding domestic violence, and it consisted of twelve questions. 


\section{Coping Strategies for Battered Women regarding Domestic Violence}

\section{Scoring system:}

The scoring system for patients' knowledge was calculated as follows (2) score for the complete correct answer, while (1) score for the incomplete correct answer, and (0) for wrong the answer. For each section of knowledge, the score of the items was summed up and the total was divided by the number of the items, giving a mean score for the part. These scores were converted into a percent score. The total knowledge score was considered good if the score of the total knowledge $\geq 75 \%$ equal and more (12) points, while considered average if it equals $50-<75 \%$ (12 - 18) point, and considered poor if it is < $50 \%$ less (12) point.

The third part: Women's practices Scale: Adapted from Smith et al., 1995. It assessed the practices of battered women toward domestic violence. Consisted of eleven questions in a three-point Likert scale.

\section{Scoring system:}

The scoring system for battered women practices was calculated as follows (2) score for always, (1) score for sometimes, and (0) for don't do the practice. The score of the items was summed- up and the total divided by the number of the items, giving a mean score. These scores were converted into a percent score. The total practices score $=(22)$; it is considered satisfactory if the score of the total practices is $\geq 60 \% \quad(\geq 13)$, while considered unsatisfactory if it is $<60 \%(<13)$.

The fourth part: Women's attitude Scale: Adapted from Carver et al., 1989. It assessed the attitude of battered women toward domestic violence. Consisted of eight questions on a three-point Likert scale.

\section{Scoring system:}

The scoring system for battered women attitudes was calculated as follows (2) score for disagree, (1) score for neutral, and (0) for agree. The score of the items was summed- up and the total divided by the number of the items, giving a mean score. These scores were converted into a percent score. The total attitude score was considered positive if the score of the total attitude $\geq 60 \%$, while considered negative if it is $<60 \%$.

Tool (II): Ways of Coping Scale: it adapted from Folkman \& Lazarus, 1986 it measures the coping abilities of battered women toward domestic violence. Consisted of nineteen questions on a three-point Likert scale.

\section{Scoring system:}

The scoring system for battered women coping scale was calculated as follows (2) score for doing it a lot, while (1) score for doing it sometimes, and (0) for never do it answer. For each section of coping skills, the score of the items was summed- up and the total divided by the number of the questions, giving a mean score for the part. These scores were converted into a percent score. The total coping score $=38$ ; it was considered high if the score of the total knowledge $>75 \%(>28)$, while considered moderate if it equals $50-75 \%(19-28)$, and considered low if it is $<50 \%$ equal or less (< 19).

\section{Content validity of the tools:}

Content validity of the tools was done by five of the Faculty's Staff Nursing experts from the Community Health Nursing Specialties who reviewed the tools for clarity, relevance,

\section{JNSBU}




\section{Lamiaa Moustafa, Nawal Soliman and Huda Abdallah Moursi}

comprehensiveness, and applicability and give their opinion.

\section{Reliability of the tools:}

Reliability of the tool was applied by the researcher for testing the internal consistency of the tool, by administration of the same tools to the same subjects under similar conditions on one or more occasions. Answers from repeated testing were compared (test-retest reliability). The reliability was done by the Cronbach's Alpha coefficient test which revealed that each of the two tools consisted of relatively homogenous items as indicated by the moderate to the high reliability of each tool. The internal consistency of the knowledge was 0.943 , practices were 0.730 , the attitude was were 0.734 , and coping was 0.622 .

\section{Ethical considerations:}

All ethical issues were assured; oral consent has been obtained from each battered woman before conducting the interview and given a brief orientation to the purpose of the study. Battered women were also reassured that all information gathered would be confidential.

This paper was used only for the purpose of the study. The battered women had the right to withdraw from the study at any time without giving any reasons.

\section{Pilot study:}

The pilot study was conducted on (10) battered women which represented $10 \%$ of the studied sample. The pilot study was aimed to test the content, clarity, applicability, and simplicity of the tool using the interviewing questionnaire and the ways of coping scale as a pre-test sheet. The estimation of the time needed to fill the questionnaire time needed to fill each sheet consumed about 30 - 45 minutes.
According to the results obtained from the data analysis, the modification rewarding, correction, omission, and addition were done. Women included in the pilot study were excluded from the total number of studied battered women samples.

\section{Fieldwork:}

Data were collected within 6 months from the start of September 2020 to end of the February 2021. The study was conducted by the researcher for the studied sample in the selected setting at the Benha and Mansoura centers of caring and hosting for battered women. The researcher visited each center two days per week from 9:00 am to 2:00 pm. The average time needed for the sheet was around $30-45$ /minutes, the average number interviewed at the center was 3-5 battered women /day depending on their responses and attendance.

\section{Coping strategies intervention:}

Based on the results obtained from the interviewing questionnaire and observational checklists, as well literature review, the coping strategies intervention developed by the researcher. It was implemented immediately after the pre-test. The researcher implemented the coping strategies intervention through 4 phases as the following:

(I) Assessment phase: In this phase of the coping strategies intervention, assessed knowledge, practices, attitude, and coping abilities of battered women through the collection and analysis of baseline data from the filled tools. In this phase, the researcher did the pre-test.

(II) Designing phase: The researcher identified the important needs for the target group, set 


\section{Lamiaa Moustafa, Nawal Soliman and Huda Abdallah Moursi}

priorities of needs, objectives, and content were developed.

\section{(III) Implementation phase:}

In this phase, the researcher implemented the coping strategies intervention for the battered women at a suitable time for them. To ensure that they were exposed to the same learning experience. The researcher implemented the coping strategies intervention through 5 hours per week (2/days) for 2 weeks on center, the total time for strategies will 20 hours on each center, each session lasted $30-45$ minutes including periods of discussion, and the average number of implementations of the coping strategies intervention were $4-6$ battered women /day, and immediately did the post-test.

\section{Teaching methods:}

All battered women received the same intervention content using the same teaching methods, there were:

- $\quad$ Lectures / discussions.

- Demonstration and re-demonstration for deep breathing and relaxing exercise.

- $\quad$ PowerPoint presentation.

- Roleplay.

\section{Teaching aids:}

Suitable teaching aids were specially prepared for intervention, as colored pictures, handouts, and videos.

\section{Phase (IV): Evaluation of the coping strategies intervention:}

After implementation of the coping strategies intervention, the researcher applied the post-test immediately to evaluate the knowledge acquired. Evaluation of the coping strategies intervention was done by using the post-test questionnaire which was the same form format as the pre-test in order to compare the change in the battered women's knowledge, practices, and attitude immediately after implementation of the strategies.

\section{Statistical analysis:}

All data collected were organized, tabulated, and analyzed using an appropriate statistical test. The data were analyzed by using the Statistical Package for Social Science (SPSS) version 22 which was applied to calculate frequencies and percentage, mean and standard deviation, as well as test statistical significance and associations by using Chisquare test (x2), and matrix correlation to detect the relationship between the variables (p-value).

\section{Significance levels were considered as follows:}

Highly statistically significant $\mathrm{P}<0.001 * *$

Statistically significant $\mathrm{P}<0.05^{*}$

Not significant

$\mathrm{P}>0.05$ 


\section{Coping Strategies for Battered Women regarding Domestic Violence}

\section{Results}

Table (1): Shows that; $44.9 \%$ of the studied battered women aged from 30 to less than 45 years old with the mean age $35.74 \pm 4.52$ and $60.7 \%$ of them were Housewife. Regarding educational level; $42.1 \%$ of the studied battered women were secondary education, $66.4 \%$ of the studied sample had not sufficient income, while $56.1 \%$ of them lived in Mansoura, 54.2 \%of the studied battered women were residing in the city, and $56.1 \%$ of them lived with husband's family home.

Table (2): Signify that; $80.4 \%$ (86 battered women) of studied battered women had chronic diseases, and $40.9 \%$ of them complained of high blood pressure and heart disease.

Table (3): Show that; $75.7 \%$ of the studied battered women were married, regarding the number of years of married $39.2 \%$ of the studied sample was 5 - <15 years, moreover $37.3 \%$ of them had 3 children and more.

Table (4): Indicate that; $71.0 \%$ of the perpetrators' persons of studied battered women were husbands, regarding their age $55.1 \%$ of perpetrators person were 41 - 61 years old, and $34.6 \%$ of perpetrators persons completed secondary school education. While $72.0 \%$ of perpetrators person of battered women studied sample had no job, and 18.7 of them was an addict.

Figure (1): Illustrates that; $76.6 \%$ of the studied battered women had high scores of economical violence, while $10.3 \%$ of them had high scores of sexual violence.

Figure (2): Illustrates that; $30.8 \%$ of the studied battered women had good scores of total knowledge about domestic violence preintervention which increased to $76.6 \%$ post- intervention. While $26.2 \%$ of them had poor total scores of total knowledge about domestic violence pre-intervention and then this percentage decreased to $11.2 \%$ postintervention.

Figure (3): Illustrates that; $35.5 \%$ of the studied battered women had satisfactory regarding total practices about domestic violence pre-intervention, and then this percentage increased to $72.0 \%$ postintervention.

Figure (4): Show that; $59.8 \%$ of the studied battered women had a positive attitude regarding domestic violence pre-intervention which decreased to $27.1 \%$ post-intervention.

Figure (5): Demonstrates that; $27.1 \%$ of the studied battered women had high coping about domestic violence pre-intervention which increased to $69.2 \%$ post-intervention. $49.5 \%$ of them had poor coping about domestic violence pre-intervention, and then this percentage decreased to $5.6 \%$ post-intervention.

Table (5): Clarifies that there was a statistically positive correlation between total knowledge and total coping, between total practices and total attitude, between total practices and total coping, and between total coping and total attitude at preprogram $(\mathrm{p}=\leq 0.05)$. Also, there was a statistically positive correlation between total knowledge and practices, between total knowledge and total attitude, between total knowledge and total coping, and between total practices and total coping, and between total attitude and total coping at post-program ( $\mathrm{p}=$ $\leq 0.05)$. 
Lamiaa Moustafa, Nawal Soliman and Huda Abdallah Moursi

Table (1): Frequency distribution of the studied battered women regarding their demographic characteristics $(n=107)$.

\begin{tabular}{|c|c|c|}
\hline Demographic characteristics & No & $\%$ \\
\hline \multicolumn{3}{|l|}{ Age } \\
\hline $15>30$ Years & 21 & 19.6 \\
\hline $30>45$ Years & 48 & 44.9 \\
\hline $45>60$ years & 31 & 29.0 \\
\hline 60 Years and more & 7 & 6.5 \\
\hline Mean \pm SD & $35.74 \pm 4.52$ & \\
\hline \multicolumn{3}{|l|}{ Educational level } \\
\hline Cannot read and write & 16 & 15.0 \\
\hline Basic education & 13 & 12.1 \\
\hline secondary school & 45 & 42.1 \\
\hline University education & 33 & 30.8 \\
\hline \multicolumn{3}{|l|}{ Occupation } \\
\hline Housewife & 65 & 60.7 \\
\hline Work & 42 & 39.3 \\
\hline \multicolumn{3}{|l|}{ Income } \\
\hline Not sufficient & 71 & 66.4 \\
\hline Sufficient & 29 & 27.1 \\
\hline Sufficient and saved from it & 7 & 6.5 \\
\hline \multicolumn{3}{|l|}{ Address } \\
\hline Benha & 47 & 43.9 \\
\hline Mansoura & 60 & 56.1 \\
\hline \multicolumn{3}{|l|}{ Residence } \\
\hline Village & 49 & 45.8 \\
\hline City & 58 & 54.2 \\
\hline \multicolumn{3}{|l|}{ Living } \\
\hline Independent house & 47 & 43.9 \\
\hline Husband's family home & 60 & 56.1 \\
\hline
\end{tabular}

Table (2): Frequency distribution of the studied battered women regarding their past medical history $(\mathrm{n}=107)$.

\begin{tabular}{|c|c|c|}
\hline \multicolumn{1}{|c|}{ Medical history } & No & \% \\
\hline high blood pressure and heart disease & 32 & 29.9 \\
\hline Diabetes & 24 & 22.4 \\
\hline asthma and chest allergy & 12 & 11.2 \\
\hline Other (n=9). & 9 & 8.4 \\
\hline$\bullet \quad$ Kidney disease & 4 & 3.7 \\
\hline$\bullet$ peptic ulcer & 4 & 3.7 \\
\hline$\bullet$ depression & 1 & .9 \\
\hline
\end{tabular}


Table (3): Frequency distribution of the studied battered women regarding their social status $(n=$ 107).

\begin{tabular}{|c|c|c|}
\hline Social Status & No & $\%$ \\
\hline \multicolumn{3}{|l|}{ Social status } \\
\hline Single & 5 & 4.7 \\
\hline Married & 81 & 75.7 \\
\hline Divorced & 11 & 10.3 \\
\hline Widow & 10 & 9.3 \\
\hline \multicolumn{3}{|c|}{$\begin{array}{l}\text { The number of years of } \\
\text { marriage for married women } \\
(\mathrm{n}=102) \text {. }\end{array}$} \\
\hline $1-<5$ Years & 24 & 23.5 \\
\hline $5-<10$ Years & 40 & 39.2 \\
\hline $10-<15$ Years & 20 & 19.6 \\
\hline 15 Years and more & 18 & 17.6 \\
\hline \multicolumn{3}{|c|}{$\begin{array}{l}\text { The number of children } \\
(\mathrm{n}=102) .\end{array}$} \\
\hline None & 19 & 18.6 \\
\hline 1 child & 12 & 11.8 \\
\hline 2 children & 33 & 32.4 \\
\hline 3 children and more & 38 & 37.3 \\
\hline
\end{tabular}

Table (4): Frequency distribution of studied battered women regarding their perpetrator's persons social status

\begin{tabular}{|c|c|c|}
\hline $\begin{array}{c}\text { The perpetrator's person } \\
\text { social status }\end{array}$ & No & $\%$ \\
\hline $\begin{array}{l}\text { The perpetrator's persons } \\
\text { who battered you is the } \\
\text { father }\end{array}$ & 9 & 8.4 \\
\hline Brother & 14 & 13.1 \\
\hline Husband & 76 & 71.0 \\
\hline father-in-law & 11 & 10.3 \\
\hline Uncle & 0 & 0.0 \\
\hline Stepfather & 0 & 0.0 \\
\hline \multicolumn{3}{|l|}{$\begin{array}{l}\text { The age of the perpetrator's } \\
\text { persons }\end{array}$} \\
\hline $20-40$ Years & 31 & 29.0 \\
\hline $41-61$ Years & 59 & 55.1 \\
\hline More than 61 years & 17 & 15.9 \\
\hline \multicolumn{3}{|l|}{$\begin{array}{l}\text { The educational level of the } \\
\text { perpetrator's persons }\end{array}$} \\
\hline Illiterate & 21 & 19.6 \\
\hline Basic education & 20 & 18.7 \\
\hline Secondary school & 37 & 34.6 \\
\hline $\begin{array}{l}\text { University and postgraduate } \\
\text { education }\end{array}$ & 29 & 27.1 \\
\hline $\begin{array}{l}\text { Does the perpetrator's } \\
\text { persons have a job? }\end{array}$ & 77 & 72.0 \\
\hline $\begin{array}{l}\text { Do perpetrators' persons } \\
\text { addict? }\end{array}$ & 20 & 18.7 \\
\hline
\end{tabular}

\section{JNSBU}




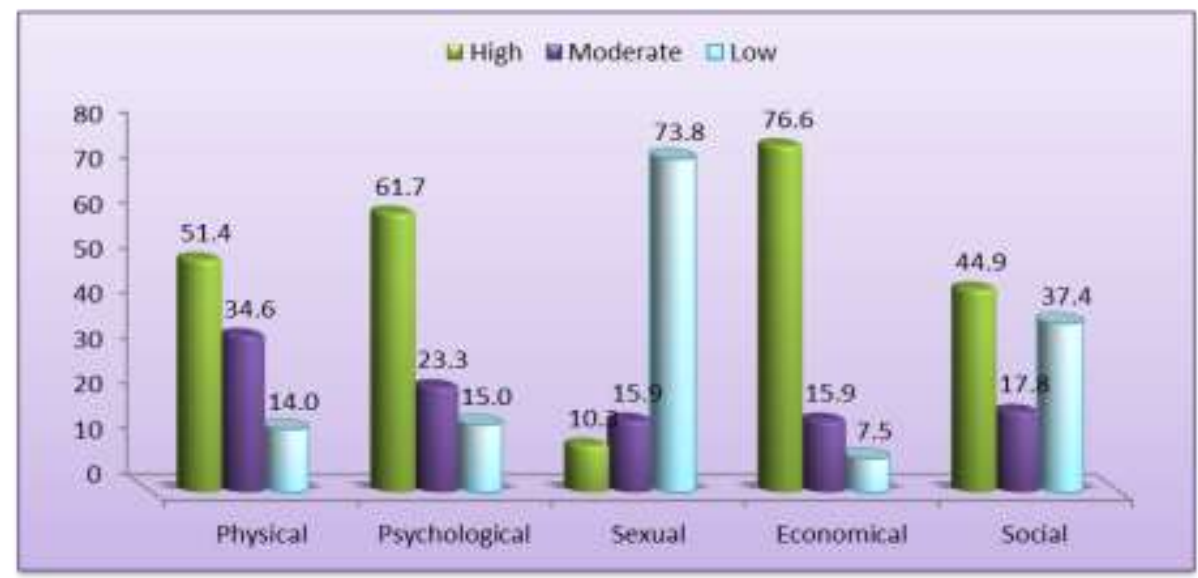

Figure (1): Percentage distribution of studied battered women regarding the severity of their different types of domestic violence $(n=107)$.

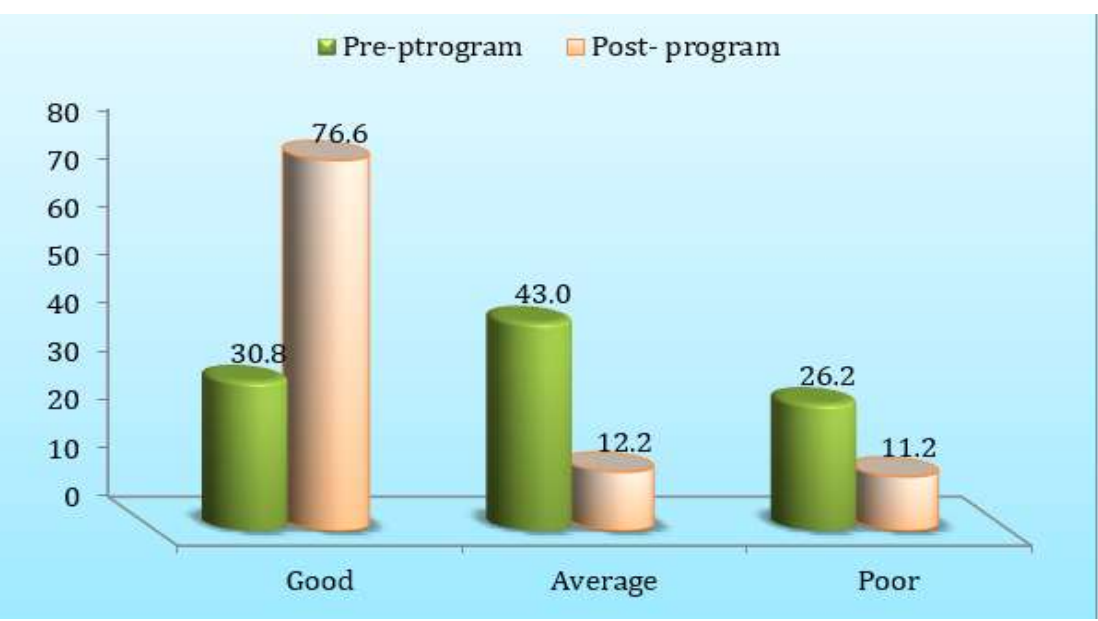

Figure (2): Percentage distribution of studied battered women regarding about domestic violence pre and post-program $(n=107)$.

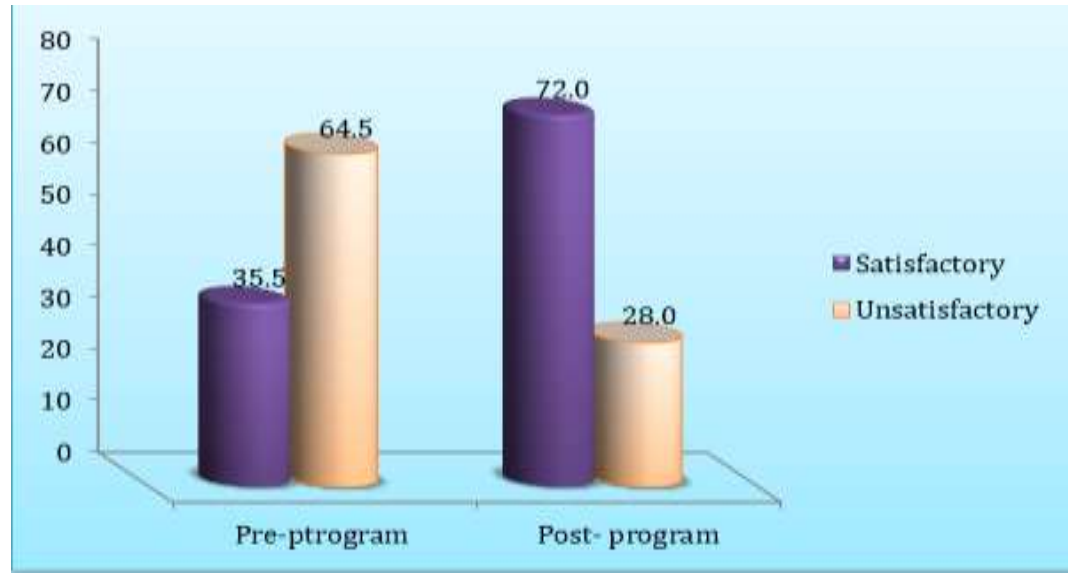

Figure (3): Percentage distribution of studied battered women regarding their total practice about domestic violence pre and post-program $(n=107)$. 
Coping Strategies for Battered Women regarding Domestic Violence

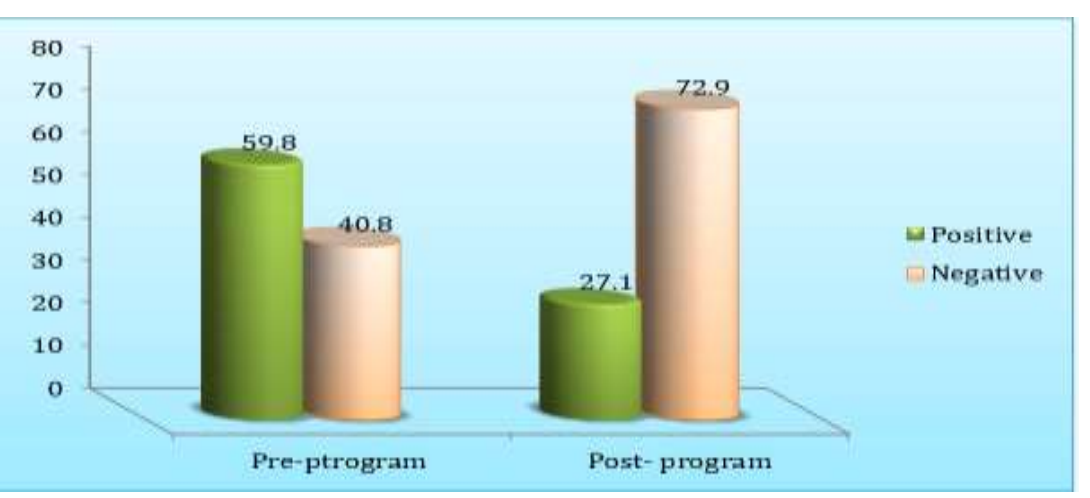

Figure (4): Percentage distribution of studied battered women regarding their total attitude of domestic violence $(\mathbf{n}=\mathbf{1 0 7})$.

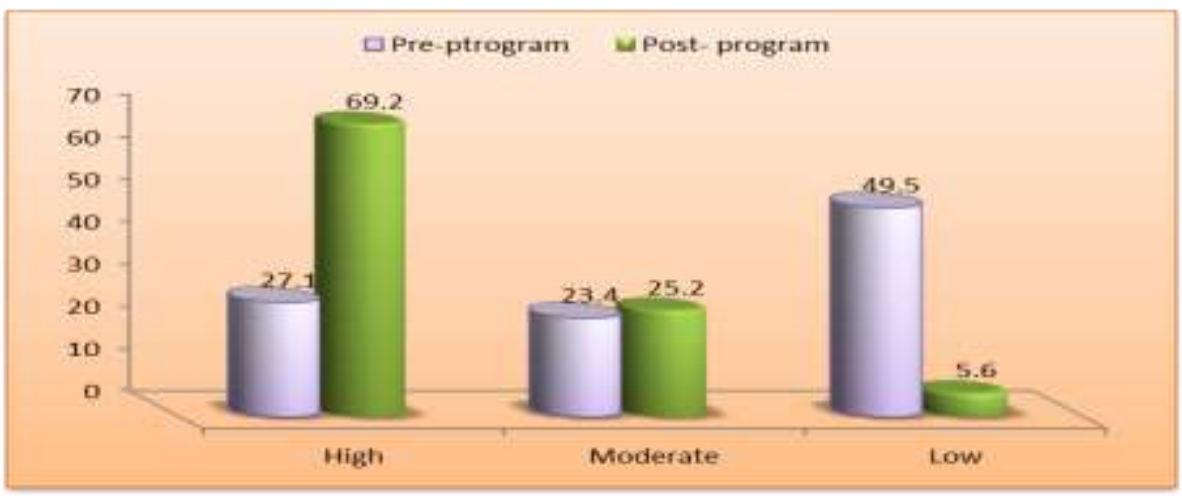

Figure (5): Percentage distribution of studied battered women regarding their total coping about domestic violence pre and post program $(n=107)$.

Table (5): Correlation matrix between total knowledge, practices, attitude, and coping among studied battered women pre and post-program $(n=107)$.

\begin{tabular}{|c|c|c|c|c|c|c|c|c|c|}
\hline & & \multicolumn{4}{|c|}{ Pre } & \multicolumn{4}{|c|}{ Post } \\
\hline & & $\begin{array}{l}\text { Total } \\
\text { Knowledge }\end{array}$ & $\begin{array}{l}\text { Total } \\
\text { practices }\end{array}$ & $\begin{array}{l}\text { Total } \\
\text { attitude }\end{array}$ & $\begin{array}{l}\text { Total } \\
\text { coping }\end{array}$ & $\begin{array}{l}\text { Total } \\
\text { Knowledge }\end{array}$ & $\begin{array}{l}\text { Total } \\
\text { practices }\end{array}$ & $\begin{array}{l}\text { Total } \\
\text { attitude }\end{array}$ & $\begin{array}{l}\text { Total } \\
\text { coping }\end{array}$ \\
\hline \multirow{3}{*}{$\begin{array}{l}\text { Total } \\
\text { Knowledge }\end{array}$} & $\mathrm{r}$ & 1 & .884 & .415 & 0.390 & 1 & .375 & .268 & .611 \\
\hline & p-value & & .014 & .080 & $.041 *$ & & $.008 *$ & $.005 *$ & $.023^{*}$ \\
\hline & $\mathrm{N}$ & 107 & 107 & 107 & 107 & 107 & 107 & 107 & 107 \\
\hline \multirow{3}{*}{$\begin{array}{l}\text { Total } \\
\text { practices }\end{array}$} & $r$ & .884 & 1 & .532 & $.290^{*-N}$ & .375 & 1 & .115 & .330 \\
\hline & p-value & .014 & & $.016^{*}$ & $.002 *$ & $.008 *$ & & .237 & .001 \\
\hline & $\mathrm{N}$ & 107 & 107 & 107 & 107 & 107 & 107 & 107 & 107 \\
\hline \multirow{3}{*}{$\begin{array}{l}\text { Total } \\
\text { attitude }\end{array}$} & $\mathrm{r}$ & .415 & .532 & 1 & .313 & .268 & .115 & 1 & .820 \\
\hline & p-value & .080 & $.016^{*}$ & & $.001 * *$ & $.005^{*}$ & .237 & & $.005^{*}$ \\
\hline & $\mathrm{N}$ & 107 & 107 & 107 & 107 & 107 & 107 & 107 & 107 \\
\hline \multirow{3}{*}{$\begin{array}{l}\text { Total } \\
\text { coping }\end{array}$} & $r$ & 0.390 & .290 & -.313 & 1 & .611 & $.330^{*-1}$ & .820 & 1 \\
\hline & p-value & $.041 *$ & $.002 *$ & $.001 * *$ & & $.023 *$ & .001 & $.005 *$ & \\
\hline & $\mathrm{N}$ & 107 & 107 & 107 & 107 & 107 & 107 & 107 & 107 \\
\hline
\end{tabular}




\section{Discussion:}

Battered women suffer from many physical, social, psychological, and mental health problems which had an impact not only on the woman but also on children and communities. The invisibility of the problem is largely attributed to the belief that it is a private family matter, which should not be made known to outsiders. Battered women usually not reported about domestic violence because of the stigma, self-blame, fear of losing their children, feelings of shame, improper judgment by others, lack of personal resources, so battered women develop learned helplessness that causes them to believe deserves the abuse and that cannot get away from it (Ana, 2017).

According to socio demographic characteristics of the studied battered women, the current study showed that half of them age from 30 to less than 45 years old with the mean age $35.74 \pm 4.52$, three-fifths of them were housewives, more than two-fifths of the studied battered women were secondary education and less than two-thirds of them had insufficient income. These findings agreed with Ashraf and Abrar-ul-Hag (2017), who studied" Domestic violence against women: Empirical evidence from Pakistan. Pertanika Journal of Social Sciences \& Humanities, University of Bahawalpur, Pakistan", and found that $53 \%$ of studied women age 30 to less than 45 years old, two fifths (40\%) of them were secondary education and less two thirds $(67 \%)$ of them had insufficient income. Therefore, it is difficult to find a job and a stable income for them. From the researcher's point of view, this might be due to developing countries having high poverty rates which lead to marriage at a young age and leaving education. Therefore, it is difficult to find a job and a stable income for them.

According to the past medical history of the studied battered women, the present study showed that more than half of them had chronic disease and less than one-third of them complained of high blood pressure and heart diseases. This finding disagrees with Roesch et al., (2020), who studied "Violence against women during covid-19 pandemic restrictions, BMJ George Mason University, Fairfax, VA, USA" and found that less than one-quarter of studied women had chronic disease and complained from high blood pressure and heart disease. From the researcher's point of view, this might be due to in many settings the health services had limited response to survivors of domestic violence. In addition, many survivors may not seek care because of ignorance of it, or they are afraid of bigger problems.

Regarding the social status of the studied battered women, the current study showed that more than three-quarters of them married, twofifths married from was $5-<15$ years, and more than one-third had 3 children. These findings agree with Sen, \& Bolsoy, (2017), who studied " Violence against women: prevalence and risk factors in a Turkish sample. BMC women's health, Manisa, Celal Bayar University" and found that three quarters $(76 \%)$ of them married, more than two fifths $(42 \%)$ of them married from was 5 - $<15$ years and more than one third had 3 children. From the researcher's point of the presence of more children who need more money and care, also some perpetrators need to have another wife after the time of marriage.

Concerning on perpetrator's social status of studied battered women, the current study showed that less than three-quarters of the perpetrator's person of studied battered women 


\section{Coping Strategies for Battered Women regarding Domestic Violence}

were husbands, more than half of them aged were 41 - 61 years old. These findings agree with Kalokhe et al., (2017), who studied "Domestic violence against women in India: A systematic review of a decade of quantitative studies. Global public health, Emory University Rollins School of Public Health, Atlanta, GA, USA" and found that three quarters $(75 \%)$ of the perpetrator's person of studied battered women were husband, more than half $(52 \%)$ of them aged were $41-61$ years old. From the researcher's point of view, this might be due to societal norms that grant men privileges and degrade women, in addition to weak legal penalties imposed on perpetrators of domestic violence.

According to the severity of different types of domestic violence of studied battered women, the current study showed that more than three-quarters of the studied battered women had high scores of economical violence, while $10.3 \%$ of them had high scores of sexual violence. The current study was in contrast with Caridade et al., (2021), who studied "Remote support to victims of violence against women and domestic violence during the COVID-19 pandemic. The Journal of Adult Protection, University of Porto, Porto, Portugal" and found that more than two thirds $(68 \%)$ of studied women had high scores sexual violence and one-quarter of them had economic violence. From the researcher's point of view, this might be due to the Coved19 crises and a lot of men leaving work and closing shops as a result of imposing partial closure and staying at home.

According to studied battered women regarding their total knowledge about domestic violence pre-and post-program. The present study revealed that less than one-third of the studied battered women had good scores of total knowledge about domestic violence preintervention which increased to more than threequarters post-intervention. While more than onequarter of them had poor total scores of total knowledge about domestic violence preintervention and then this percentage decreased to less than one-eight post-intervention. These findings are in the same line with Vieira et al., (2020), who found that more than one quarter (27\%) of them had poor total scores of total knowledge about domestic violence preintervention and then this percentage decreased to less than one eight (11\%) post-intervention. This might be due to the efficiency and comprehensiveness of the information provided and helped improve their knowledge.

Regarding studied battered women total practices toward domestic violence pre-and postprogram implementation, the present study revealed that; more than one-third of the studied battered women had satisfactory regarding total practices about domestic violence preintervention, and then this percentage increased to less than three-quarters post-intervention. This finding within contrast with Walby et al., (2017), who studied "The concept and measurement of violence against women, Lumsa University, UK" and found that more than twothirds of the studied battered women had satisfactory regarding total practices about domestic violence pre-intervention, and then this percentage increased to most (86\%) postintervention. This might be due to the high level of education which makes practice well.

Concerning on studied battered women regarding their total attitude about domestic violence pre-and post-program. The current study showed that; three-fifths of the studied battered women had a positive attitude regarding 


\section{Lamiaa Moustafa, Nawal Soliman and Huda Abdallah Moursi}

domestic violence pre-intervention which decreased to more than one-quarter postintervention. This finding agrees with Kiani, (2020), who studied "Women experiencing domestic violence: A qualitative study. Journal of qualitative Research in Health Sciences, Isfahan University, Iran" and found that three fifths $(59.6 \%)$ of the studied sample had a positive attitude regarding domestic violence pre-intervention which decreased to more than one quarter $(26 \%)$ post-intervention. This might be due to battered women's postintervention understanding that domestic violence is not a normal part of life and perpetrates have not any right to violet them.

According to studied battered women regarding their coping with domestic violence pre-and post-program. The present study illustrated that there was a highly statistically significant difference in all items studied battered women's coping toward domestic violence pre-and post-program implementation $(p \leq 0.001)$, more than one-quarter of the studied battered women had high coping about domestic violence pre-intervention which increased to less than three-quarters postintervention. This finding agreed with Signorelli et al., (2018), who studied "Domestic violence against women, public policies and community health workers in Brazilian Primary Health Care, Saúde Coletiva, Universidad, Brasil" and found that more than one quarter $(27 \%)$ of the studied battered women had high coping about domestic violence pre-intervention which increased to three quarters (76\%) postintervention. From the researcher's point of view, this might be due to learning new practices about coping strategies, and becoming more understanding of domestic violence knowledge so their attitude becomes more negative to word accept domestic violence as a part of life.

The present study revealed that there was a statistically positive correlation between total knowledge, total coping, total practices, and total attitude pre and post-program $(\mathrm{p}=\leq 0.05)$. This is in the same line with Stöckl et al., (2021), who studied" Physical, sexual and psychological intimate partner violence and nonpartner sexual violence against women and girls: a systematic review protocol for producing global, regional and country estimates. BMJ open, University of Valencia, Valencia, Spain" and found that there was a statistically positive correlation between total knowledge, total coping, total practices, and total attitude pre-and post-program. This might be due to good knowledge effect on practice that led to right coping and have a good attitude.

\section{Conclusion:}

The coping strategies succeeded to improve the knowledge, practices, attitude, and coping abilities of battered women. More than two-thirds of the studied battered women had good knowledge post coping strategies intervention, more than two-thirds of the studied battered women had satisfactory practices post coping strategies intervention, more than onequarter of the studied battered women had positive attitude regarding domestic violence post coping strategies intervention, and more than two-thirds of studied battered women had high coping abilities about domestic violence post coping strategies intervention. There was a positive statistically significant correlation between the studied battered women's total coping abilities score and total practices score, 


\section{Coping Strategies for Battered Women regarding Domestic Violence}

total knowledge score, and total attitude score pre-intervention and post-intervention.

\section{Recommendation:}

1- Continuous coping strategies intervention for battered women with domestic violence to increase their knowledge, improve their practices, strengthen their behavior, and enhance their coping abilities especially at centers for care and hosting of abused women and generally in the community.

2- Emphasize the importance of providing governmental and non-governmental support and appropriate follow-up for battered women with domestic violence in all centers for care and hosting of abused women by specialized staff in order to prevent post-traumatic stress syndrome complications.

3 - Further research is proposed to explore the effect of coping strategies intervention on the prevention of domestic violence among a large sample size.

\section{References:}

Ana Turprats (2017). Unemployment and intimate - partner violence: agender - identity approach.

Ashraf, S., and Abrar-ul-Haq, M., (2017). Domestic violence against women: Empirical evidence from Pakistan. Pertanika Journal of Social Sciences \& Humanities, 25(3): P 1401 1418.

Caridade, M., Saavedra, R., Ribeiro, R., Oliveira, C., Santos, M., Almeida, I. S., \& Soeiro, C. (2021). Remote support to victims of violence against women and domestic violence during the COVID-19 pandemic. The Journal of Adult Protection V 23( 4): P107.

Carver, C. S., Scheier, M. F., \& Weintraub, J. K. (1989). Assessing coping strategies: A theoretically based approach, Journal of
Personality and Social Psychology. 56, 267-283. Folkman, S., \& Lazarus, R. S. (1986). Stress, Appraisal and Coping, Journal of Behavioural and Cognitive Psychotherapy, Cambridge University Press. Vol 14 (4): 345.

Kalokhe, A., Del Rio, C., Dunkle, K., Stephenson, R., Metheny, N., Paranjape, A., \& Sahay, S. (2017). Domestic violence against women in India: A systematic review of a decade of quantitative studies. Global public health, 12(4): P 498-513.

Kiani, M. (2020). Women experiencing domestic violence: A qualitative study. Journal of qualitative Research in Health Sciences, 3(1), 14-26.

Mahapatro, M. (2018). Domestic violence and healthcare in India-Policy, and practice. Singapore: Springer Nature.

Roesch, E., Amin, A., Gupta, J., \& GarcíaMoreno, C. (2020). Violence against women during covid-19 pandemic restrictions, BMJ 2020,369:m1712.

Salvatore, T. (2018). Intimate partner violence: A pathway to suicide. FBI Law Enforcement Bulletin. Retrieved from

Sen, S., \& Bolsoy, N. (2017). Violence against women: prevalence and risk factors in Turkish sample. BMC women's health, 17(1): P 1-9.

Signorelli, M. C., Taft, A., \& Pereira, P. P. G. (2018). Domestic violence against women, public policies and community health workers in Brazilian Primary Health Care. Ciência \& Saúde Coletiva, 23, 93-102.

Smith PH, Earp JL, DeVellis R. Measuring battering (1995). Development of the Women's Experience with Battering (WEB) scale, Women's Health: Research on Gender, Behavior, and Policy. vol 1(4):273-288. 
Stöckl, H., Sardinha, L., Maheu, M., Meyer, R., and García-Moreno, C. (2021). Physical, sexual and psychological intimate partner violence and non-partner sexual violence against women and girls: a systematic review protocol for producing global, regional and country estimates. BMJ, 11(8), e045574

Taylor Shelley (2012). Coping Strategies, University of California, San Francisco,

Tomasz Iwanski (2019).Nurse in the Process of Preventing Domestic Violence, Medical \& Clinical Research, Volume 4, Issue 8, 1 - 5.

UNFPA (United Nations Population Fund Activities) (2019). WHAT WE DO: Genderbased violence. Available at https:/ legypt.unfpa.org/en/node/22540. Accessed on 11-1-2021

Vieira, R., Garcia, P., and Maciel, N. (2020). The increase in domestic violence during the social isolation: what does it reve, Revista Brasileira de Epidemiologia, P23.

Walby, S., Towers, J., Balderston, S., Corradi, C., Francis, B., Heiskanen, M, and Strid, S. (2017). The concept and measurement of violence against women and men,PMC, (p. 192).

WHO (2021). Violence against women Prevalence Estimates, 2018. Global, regional and national prevalence estimates for intimate partner violence against women and global and regional prevalence estimates for nonpartner sexual violence against women.: Geneva.

WHO (2016). Violence against Women: Intimate Partner and Sexual Violence against women. Factsheet No. 239. Geneva: WHO. 


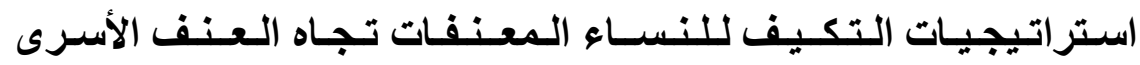



يُمثنل العنف الاسرى تحدياً مهماً وله عو اقب وخيمة على الصحة العامة للنساء ، كما أن له تأثثر سلبى على التقدم الإقتصادى للبلدان وذلك عن طريق فقدان ساعات عمل النساء وزيادة تكاليف الرعاية الصحية ، لذلك هدفت هذة الرسالة إلى تقييم فاعلية تطبيق استراتيجيات التكيف للنساء المُعنفات تجاه العنف الاسرى. وقد أجريت هذة الدر اسة فى مركزين لرعاية واستضافة المر أة المُعنفة تابعين لوزارة التضامن الاجتماعى بمحافظتى القليوبية

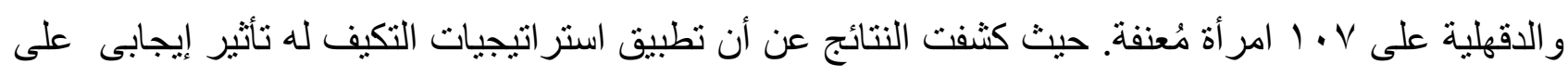
معلومات وممارسات و إتجاهات النساء المعنفات بالإضافة لتحسين قدر اتهن على التكيف. كما أوصت الدراسة على تقديم استر اتيجيات التكيف باستمر ار للنساء المُعنفات لزيادة معرفتهن وتحسين ممارستهن وتعديل سلوكهن وتعزيز قدر اتهن على التكيف خاصة النساء المترددات على مر اكز رعاية واستضافة النساء المُعنفات. 